\title{
The impact of impoundment on the rotifer communities in two tropical floodplain environments: interannual pulse variations
}

\author{
Bonecker, CC.*, Aoyagui, ASM. and Santos, RM. \\ Departamento de Biologia, Programa de Pós-Graduação em Ecologia de Ambientes Aquáticos Continentais, \\ Núcleo de Pesquisas em Limnologia Ictiologia e Aqüicultura, Universidade Estadual de Maringá - UEM, \\ Av. Colombo, 5790, CEP 87020-900, Maringá, PR, Brazil \\ *e-mail: claudiabonecker@gmail.com
}

Received November 10, 2008 - Accepted March 4, 2009 - Distributed June 30, 2009

(With 3 figures)

\begin{abstract}
Hydrological pulses are the main factor regulating the structure of biological communities in floodplains. Reservoirs above this ecosystem change the environment's dynamics and the community's biodiversity. This study evaluated the structure and stability of the rotifer community in response to changes in hydrological pulses after the Porto Primavera impoundment in the Upper Paraná River floodplain. The community was studied in a river and in a floodplain lake downstream of the dam over a four-year period before and after the impoundment. A decrease in species richness and abundance was observed soon after the impoundment, followed by an increase in these attributes and in specific diversity when the hydrometric level of the Paraná River rose and, consequently, increased the connectivity between the floodplain environments. Conochilus coenobasis, Filinia longiseta, Keratella cochlearis, Lecane proiecta and Polyarthra dolichoptera persisted throughout the study and contributed to community stability (the maintenance of rank in species abundance over time), which was high in the floodplain lake, mainly after the impoundment. Reductions in the frequency, intensity and amplitude of potamophase pulses after the impoundment led to the decrease in species richness and the increases in abundance, community stability, and species diversity, which determine community resilience.
\end{abstract}

Keywords: rotifer, floodplain, reservoirs, Paraná River, Brazil.

\section{O impacto de represamentos sobre comunidades de rotíferos em dois ambientes de planície tropical: variações interanuais nos pulsos hidrológicos}

\begin{abstract}
Resumo
O principal fator regulador da estrutura das comunidades biológicas nas planícies de inundação é o regime de pulsos hidrológicos. Reservatórios construídos nesses ecossistemas alteram a dinâmica dos ambientes e a biodiversidade das comunidades. Este estudo avaliou a estrutura e a estabilidade da comunidade de rotíferos em conseqüência das alterações do pulso hidrológico após o represamento de Porto Primavera, na planície de inundação do Alto Rio Paraná, a montante. A comunidade foi estudada em um rio e uma lagoa, durante quatro anos, antes e depois da construção do reservatório. Logo após o represamento, foi observada a redução da riqueza de espécies e abundância dos organismos, seguida do incremento destes atributos, e da diversidade de espécies com o aumento do nível hidrométrico do Rio Paraná e, conseqüentemente, da conectividade entre os ambientes da planície de inundação em anos de cheias excepcionais. Conochilus coenobasis, Filinia longiseta, Keratella cochlearis, Lecane proiecta e Polyarthra dolichoptera persistiram durante o estudo, contribuindo para a estabilidade da comunidade (manutenção da abundância das espécies ao longo do tempo), que foi maior na lagoa, principalmente após o represamento. A redução na frequiência, intensidade e amplitude dos pulsos de potamofase determinaram, por um lado, a redução da riqueza de espécies, e por outro o aumento da abundância dos organismos e da estabilidade da comunidade, além do aumento da diversidade de espécies, favorecendo a persistência da comunidade.
\end{abstract}

Palavras-chave: rotíferos, planície de inundação, reservatórios, Rio Paraná, Brasil.

\section{Introduction}

Floodplains are highly dynamic ecosystems presenting remarkable environmental heterogeneity, including lakes, channels and flooded areas associated with large rivers. These ecosystems are characterized by periodical distur-

bances due to variations in the hydrological regime of the main river. Based on spatial and temporal features, high aquatic biodiversity has been recorded in these ecosystems (Junk et al., 1989; Neiff, 1990; Ward et al., 1999). 
The pulse regime, described in terms of potamophase and limnophase, is interpreted from the frequency, intensity, tension, recurrence, amplitude and seasonality of the hydrometric level, and this regime is considered to be the main factor regulating the structure of biological communities in floodplains (Junk et al., 1989; Neiff, 1990; 2001). These hydrological attributes are strongly affected by the operational procedures of upstream reservoirs. In the Upper Paraná River floodplain, this regulation has led to a decreasing lag in the frequency and intensity of pulses (Agostinho et al., 2004).

At the end of 1998, the Porto Primavera Reservoir (São Paulo State) was totally filled; this impoundment, besides inundating half of the Upper Paraná River floodplain, changed the pulse regime in the remaining area, which is currently the last dam-free stretch inside Brazilian territory (Agostinho et al., 2004). Before this impoundment, oscillations of hydrometric levels in this stretch still displayed seasonality, although the great influence of upstream reservoirs had already been noticed (Agostinho et al., 2004). Following the impoundment of Porto Primavera Reservoir, an absence of seasonal patterns of hydrometric levels was verified (Rocha and Thomaz, 2004). Flood periods can still be observed during some periods when global climatic events are predominant, such as El Nino.

The rotifer plankton community displays high species diversity in the Upper Paraná River floodplain. These organisms are characterized as opportunistic, consuming and assimilating a wide variety of food resources with a high turnover rate and high tolerance to environmental conditions, resulting in a much more diverse community in the environments of this fluvial macrosystem (Allan, 1976; Bozelli, 2000; Neves et al., 2003).

We evaluated interannual variations in the species richness, abundance, composition, species dominance, persistence and stability of the rotifer community in a river and in a floodplain lake under the influence of the pulse regime before and after Porto Primavera Reservoir became operational. We predicted that all of these community attributes would be lower after the impoundment in response to changes in the hydrological regime of the floodplain located downstream from the reservoir.

\subsection{Study area}

We selected two environments to carry out this study: Baía River and Guaraná Lake (Figure 1). Baía River $\left(22^{\circ} 43^{\prime} \mathrm{S}\right.$ and $53^{\circ} 17^{\prime} \mathrm{W}$ ) is connected to the Paraná River through a channel, which has a strong influence on the Baía's rate of flow. The floodplain lake $\left(22^{\circ} 43^{\prime} \mathrm{S}\right.$ and $53^{\circ} 18^{\prime} \mathrm{W}$ ) is located near the right bank of the Baía River and is connected to this river through a permanent channel $70 \mathrm{~m}$ long and $18 \mathrm{~m}$ wide. This floodplain lake has a rounded shape, and is $387 \mathrm{~m}$ in length, $1.058 \mathrm{~m}$ in perimeter, $4.2 \mathrm{~km}$ in area and with a mean depth of $2.1 \mathrm{~m}$.

\section{Material and Methods}

The hydrometric level (m) of the Paraná River was obtained from the Porto São José hydrometric station on the right bank of the river and was provided by Itaipu Binacional. We calculated: i) the amplitude of limnophase and potamophase pulses; and ii) the connectivity index between the floodplain and the studied environments (ratio of the number of days under potamophase and limnophase) (Neiff, 1990) using the PULSO software (Neiff and Neiff 2003). The reference hydrological level of the Paraná River was 3.5 m (Thomaz et al., 2004).

Samplings were undertaken in one sampling station in each environment every three months at the subsurface in the pelagic region in 1992 (before the impoundment), 2000, 2001 and 2002 (after the impoundment). Rotifer samplings were carried out using a motorized pump and plankton net $(68 \mu \mathrm{m})$ to filter $1000 \mathrm{~L}$ of water per sample. The material was preserved in formaldehyde $(4 \%)$ buffered with calcium carbonate.

Species richness was analyzed under an optical microscope until the stabilization of the species accumulation curve. Individuals were identified using specific bibliographies. Abundance was determined using a Sedgewick-Rafter chamber under an optical microscope. At least 80 individuals were counted (Bottrell et al., 1976) in three subsequent samples obtained with a Hensen-Stempell pipette $(2.5 \mathrm{~mL})$.

Species diversity in the environments and over time was estimated from the species dominance curve, persistence of species and alpha diversity (the number of species found in each sample). Changes in the community composition over time in both environments were evaluated through the Beta-1 $\left(\beta_{1}\right)$ and Beta-2 $\left(\beta_{2}\right)$ indices (Whittaker, 1960).

Two-way ANOVA (Sokal and Rolhf, 1981) was employed in order to test the influence of temporal and spatial variations on species richness and abundance. Afterwards, a linear regression analysis was performed between species richness and abundance to evaluate the effect of number of individuals on the number of species (Zar, 1999).

Stability was defined as the ability of the system to resist a disturbance and return to its original state (McCann, 2000; Pimm, 1984), and for the communities, it was considered as the maintenance of rank in the species abundance over time (Connell and Sousa, 1983; Scarsbrook, 2002). It was estimated using the Spearman correlation coefficient between the rank of the abundance of species occurring in the river and in the floodplain lake over time (Connell and Sousa, 1983). The species considered here were those occurring during the four sampling years in the two environments separately (mean of four sampling months in each environment). Positive and significant correlations indicate that the species kept their positions in the abundance ranking despite the hydrological variation among sampling years.

The significance level adopted in these analyses was $\mathrm{p}<0.05$, and the data of species richness and abundance were previously $\log$ transformed $(\log x+1)$ to satisfy the assumptions of normality and homoscedasticity. 


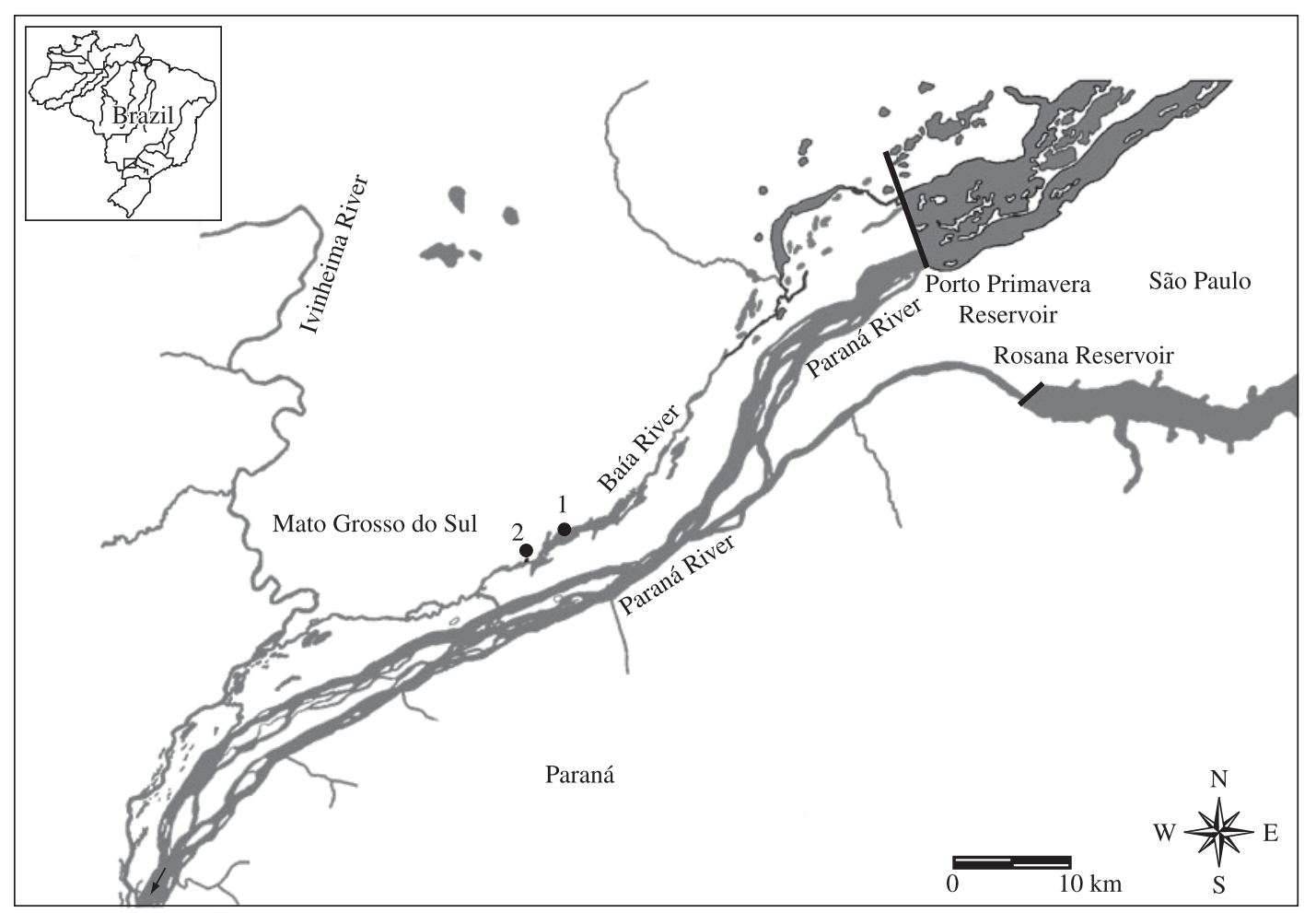

Figure 1. Study area and sampling environments ( 1 = Baía River, 2 = Guaraná Lake).

Analyses were performed using Statistica software, version 7.1 (Statsoft Inc., 2005).

\section{Results}

\subsection{Hydrological cycle}

Daily hydrometrical levels of the Paraná River were used to characterize the hydrologic phase of each year (Table 1). The year of 1992, before the impoundment, was characterized by the occurrence of 4 potamophase and 2 limnophase pulses, i.e., a typical year with expansion and retraction of water on the floodplain (Table 1).

During 2000 and 2001, after the impoundment, the daily hydrometrical levels surpassed $3.5 \mathrm{~m}$ for a few days, especially in March 2000. In this period, only 1 potamophase occurred, lasting 4 days, with a mean value of $3.7 \mathrm{~m}$. The limnophase ranged from 14 to 106 days in length, with a mean hydrometrical level of $2.1 \mathrm{~m}$. In 2001, we also recorded only 1 potamophase, lasting 7 days, with a mean value of $3.58 \mathrm{~m}$. The limnophase periods varied between 21 and 293 days in duration, with a mean level of $2.68 \mathrm{~m}$ (Table 1). These results indicate that the environments were flooded for a short period of time in both years, with maximum values during the potamophase close to the initial level of flooding (3.5 m); thus, limnophase pulses prevailed within both each month and each year. These years were atypical and characterized as extremely dry.

The year of 2002 also presented a long period of limnophase, with five pulses ranging from 5 to 247 days and a mean intensity of $3.07 \mathrm{~m}$. In this year, 2 potamophase pulses were also registered, with a mean value of $3.90 \mathrm{~m}$ and durations from 10 to 15 days. Despite the extended period of limnophase, we observed that the mean value of pulses from this period was superior to those recorded in the 2 previous years and similar to the mean value registered in 1992. The mean value of the potamophase pulses was also higher than that verified in previous years (Table 1).

The connectivity index between the Paraná River and the floodplain indicated the occurrence of greater connectivity between the river and the floodplain in 1992 and after the impoundment in 2002. The amplitude of the potamophase period was also clearly higher before the impoundment, in 1992. On the other hand, in other years, the limnophase duration was pronounced, despite the occurrence of a longer potamophase period in 2002 than in 2000 and 2001 (Table 1).

\subsection{Composition and $\alpha$ diversity}

We identified 149 rotifer species, and among these species, 7 new records were registered for the floodplain Encentrum saundersiae (Hudson, 1885), Euchlanis deflexa (Gosse, 1851), Lecane robertsoneae (Segers, 1993), Lepadella triptera (Ehrenberg, 1832), 
Table 1. Pulse attributes analyzed for the Upper Paraná River floodplain during the potamophase (P) and limnophase (L) in 1992, 2000, 2001 and 2002.

\begin{tabular}{|c|c|c|c|c|c|c|c|c|}
\hline & \multicolumn{2}{|c|}{1992} & \multicolumn{2}{|r|}{2000} & \multicolumn{2}{|r|}{2001} & \multicolumn{2}{|c|}{2002} \\
\hline & $\mathbf{P}$ & $\mathbf{L}$ & $\mathbf{P}$ & $\mathbf{L}$ & $\mathbf{P}$ & $\mathbf{L}$ & $\mathbf{P}$ & $\mathbf{L}$ \\
\hline Number of pulses & 4 & 2 & 1 & 10 & 1 & 4 & 2 & 5 \\
\hline Pulse level (m) & 4.41 (mean) & 3.10 (mean) & 3.70 & 2.10 (mean) & 3.58 & 2.68 (mean) & 3.90 (mean) & 3.07 (mean) \\
\hline $\begin{array}{l}\text { Pulse amplitude } \\
\text { (max-min) (days) }\end{array}$ & 80-28 & $137-13$ & 4 & 106-14 & 7 & 293-21 & 15-10 & $247-5$ \\
\hline Number of days & 196 & 169 & 27 & 339 & 10 & 355 & 51 & 314 \\
\hline Connectivity index & \multicolumn{2}{|c|}{1.166} & \multicolumn{2}{|r|}{0.080} & \multicolumn{2}{|r|}{0.028} & \multicolumn{2}{|c|}{0.162} \\
\hline Characterization & \multicolumn{2}{|c|}{$\begin{array}{l}\text { Typical year with } \\
\text { expansion and retraction } \\
\text { of water on the floodplain }\end{array}$} & \multicolumn{2}{|c|}{$\begin{array}{l}\text { Atypical year, } \\
\text { extremely dry, } \\
\text { low connectivity } \\
\text { between the river } \\
\text { and the floodplain }\end{array}$} & \multicolumn{2}{|c|}{$\begin{array}{l}\text { Atypical year, } \\
\text { extremely dry, } \\
\text { extremely low } \\
\text { connectivity } \\
\text { between the river } \\
\text { and the floodplain }\end{array}$} & \multicolumn{2}{|c|}{$\begin{array}{l}\text { Atypical year, dry, with } \\
\text { increase in the } \\
\text { potamophase periods } \\
\text { and in the connectivity } \\
\text { between the river and the } \\
\text { floodplain }\end{array}$} \\
\hline
\end{tabular}

Sinantherina ariprepes (Edmondson, 1939), Trichocerca myersi (Hauer, 1931), T. plaka (Myers, 1938), although with low occurrence.

\subsection{Species richness and abundance}

Alpha diversity results evidenced that, in general, the floodplain lake presented the highest number of species per sample. The highest values were observed in 2002, followed by 1992, 2001 and 2000, and during this last year, the values verified were rather low (Table 2). The highest values were observed during the potamophase periods. The ANOVA results evidenced higher values during the potamophase $\left(\mathrm{F}_{(1,29)}=6.527 ; \mathrm{p}=0.039\right)$.

Greater abundance was also verified in the floodplain lake, especially in 2001, when an increase in the abundance was also observed in the river. In this year only limnophase pulses were observed (Table 2), which influenced mainly the rotifers' abundance in the floodplain lake, although there were no observed significant differences over time and space.

The linear regression analysis pointed out the lack of relationships between species richness and abundance, both over space and time. The highest species richness registered in the floodplain lake and in the river was recorded in times of intermediate abundance values. Both results were observed during potamophase in 1992 and limnophase in 2002.

\subsection{Dominance, species diversity and persistence}

In the river, the highest species richness was recorded in 2002 (68 species), and, according to the species dominance curve, the highest specific diversity was also observed in this year (Figure 2). Lecane proiecta (Hauer, 1956) was the only species that persisted in the river, with high abundance during the 4 studied years and expressive dominance between 2000 and 2002 (Figure 2). Other species persisted in other years: Brachionus calyciflorus (Pallas, 1766), Conochilus coenobasis (Skorikov, 1914), Polyarthra dolichoptera
(Idelson, 1925) and Synchaeta pectinata (Ehrenberg 1832) in 2000 and 2001; Filinia opoliensis (Zacharias, 1891) and Lecane bulla (Gosse, 1886) in 2000 and 2002; Keratella cochlearis (Gosse, 1851) in 1992 and 2002; Trichocerca iernis (Gosse, 1887) in 2001 and 2002; and Euchlanis dilatata (Ehrenberg, 1832), Filinia longiseta (Ehrenberg, 1834), and Ploesoma truncatum (Levander, 1894) in 1992, 2000 and 2001.

In the floodplain lake, the highest species richness was also recorded in 2002 (79 species), and from the species dominance curve, a higher specific diversity was recorded in 2000 and 2002 (Figure 2). Unlike that found in the river, no species persisted in the floodplain lake with high abundance during the 4 studied years (Figure 2). The species that persisted in this environment with high abundances for some periods of time were Keratella americana (Carlin, 1943) (in 1992 and 2000), Brachionus mirus (Daday, 1905) and Polyarthra vulgaris (Carlin, 1943) (in 1992 and 2001), Keratella cochlearis (in 1992 and 2002), Filinia longiseta (Ehrenberg, 1834) (in 2000 and 2002), Conochilus coenobasis and Polyarthra dolichoptera (in 2000 and 2001), and Brachionus falcatus (Zacharias, 1898) and Lecane proiecta (in 2001 and 2002).

\section{5. $\beta$ diversity and community stability}

The values of $\beta_{1}$ and $\beta_{2}$ diversities indicated clear variations in species composition in the 2 environments over the years, with higher values in 2000 and 2002 (mainly in 2000 for the river; Figure 3).

Spearman correlations performed between the species occurring in the river during all sampling years (14 species: Brachionus calyciflorus, B. dolabratus (Harring, 1915), B. falcatus, B. mirus, Euchlanis dilatata, Filinia longiseta, F. opoliensis, Keratella americana, K. cochlearis, Lecane bulla, L. proiecta, Ploesoma truncatum, Trichocerca cylindrica (Imhof, 1891) and T. pusilla (Lauterborn, 1898) evidenced that the stability of rotifer assemblages was maintained only between 2001 and $2002(r=0.68)$ (Table 3). 
Table 2. Abundance $\left(\mathrm{AB}\right.$; ind. $\left.\mathrm{m}^{-3}\right)$ and species richness $(\mathrm{RI})$ of the rotifer community in two environments (LG $=$ lake, $\mathrm{RV}=$ river) of the Upper Paraná River floodplain during the hydrological periods (HP) of potamophase (P) and limnophase (L) in 1992, 2000, 2001 and 2002.

\begin{tabular}{rlcrlrllrl}
\hline Year & EN & HP & AB & RI & Year & EN & HP & \multicolumn{1}{c}{ AB } & RI \\
\hline 1992 & LG & P & 12,115 & 46 & 2001 & LG & L & 104,030 & 27 \\
& LG & L & 6,800 & 46 & & LG & L & 172,620 & 32 \\
& LG & L & 23,350 & 29 & & LG & L & 727,793 & 22 \\
& LG & P & 33,262 & 47 & & LG & L & $1,715,637$ & 30 \\
& RV & P & 18,824 & 29 & & RV & L & 153,614 & 27 \\
& RV & L & 7,412 & 35 & & RV & L & 69,279 & 31 \\
& RV & L & 33,722 & 24 & & RV & L & 109,752 & 26 \\
& RV & P & 58,941 & 36 & & RV & L & 25,588 & 26 \\
& LG & L & 5,444 & 20 & 2002 & LG & L & 13,074 & 59 \\
& LG & L & 19,147 & 13 & & LG & P & 36,917 & 46 \\
& LG & L & 3,615 & 28 & & LG & L & 88,359 & 57 \\
& LG & L & 3,034 & 25 & & LG & L & 300,524 & 37 \\
& RV & L & 30,334 & 26 & & RV & L & 10,029 & 44 \\
& RV & L & 6,578 & 15 & & RV & P & 42,008 & 37 \\
& RV & L & 1,948 & 18 & & RV & L & 35,087 & 36 \\
& RV & L & 10,102 & 13 & & RV & L & 67,857 & 34 \\
\hline
\end{tabular}

In the floodplain lake, 22 rotifer species (Ascomorpha ecaudis (Perty, 1850), Brachionus falcatus, B. mirus, B. quadridentatus (Hermann, 1783), Dipleuchlanis propatula (Gosse, 1886), Euchlanis dilatata, E. incisa (Carlin, 1939), Filinia longiseta, Keratella americana, K. cochlearis, K. lenzi (Hauer, 1953), Lecane bulla, L. curvicornis (Murray, 1913), L. leontina (Turner, 1892), L. proiecta, Plationus patulus (O. F. Müller,1786), Platyias quadricornis (Daday, 1905), Polyarthra vulgaris, Testudinella patina (Hermann, 1783), Trichocerca bicristata (Gosse, 1886), T. cylindrica and T. pusilla) were observed during the four sampling years. The correlation analysis indicated significant results between 1992 and $2001(\mathrm{r}=0.45)$ and $2002(\mathrm{r}=0.45)$, between 2000 and $2002(\mathrm{r}=0.51)$, and the most pronounced result, between 2001 and $2002(r=0.74)$ (Table 3).

\section{Discussion}

Studies of the Upper Paraná River floodplain have pointed out that the hydrological regime of this river is the main factor explaining the dynamic of this ecosystem and consequently the dynamics of the aquatic communities (Agostinho et al., 2004; Rocha and Thomaz, 2004; Lansac-Tôha et al., 2009). This influence was seen in the structure and dynamics of the rotifer community in our study. The impoundment of Porto Primavera Reservoir reduced the amplitude of the pulses due to the operational procedures of the hydroelectric power plant, corroborating the Serial Discontinuity Concept (Ward and Stanford, 1995a).

The highest species richness recorded before the impoundment (1992) coincided with the well-defined periods of potamophase and limnophase and high con- nectivity between the river and the floodplain. Ward and Stanford (1995a), Ward and Tockner (2001), Thomaz et al. (2007) and Alho (2008) highlighted the importance of hydrological connectivity among the environments in flooding areas for the maintenance of biodiversity. Studies by Lansac-Tôha et al. (2004), Aoyagui and Bonecker (2004) and Bonecker et al. (2005) indicated that there is high fauna exchange during the potamophase due to the great connectivity between the floodplain environments and the compartments (littoral and pelagic zones) in the environments. In the case of the rivers, Bonecker et al. (2005) stated that the rotifer species richness in these environments tends to increase during flooding due to the contribution of periphytic and benthonic taxa in the water column. Velho et al. (2004) argued that the rivers function as storage for fauna present throughout the floodplain.

On the other hand, soon after the impoundment (2000) the species richness sharply decreased, then increased gradually in the following years until reaching values similar to the previous phase. This pattern of interannual variation was also verified for alpha diversity. The reduction in the water column in 2000 led to greater isolation of environments, emphasized by the reduction in the connectivity index and the expressive increase in the number and amplitude of limnophase pulses, with the lowest mean hydrometrical level during the study. In this year, a single potamophase pulse was registered, which lasted only 4 days and had a mean level of $3.70 \mathrm{~m}$. According to Rocha and Thomaz (2004), changes in the physical and chemical conditions of the water were also observed in the tested environments during this year, 

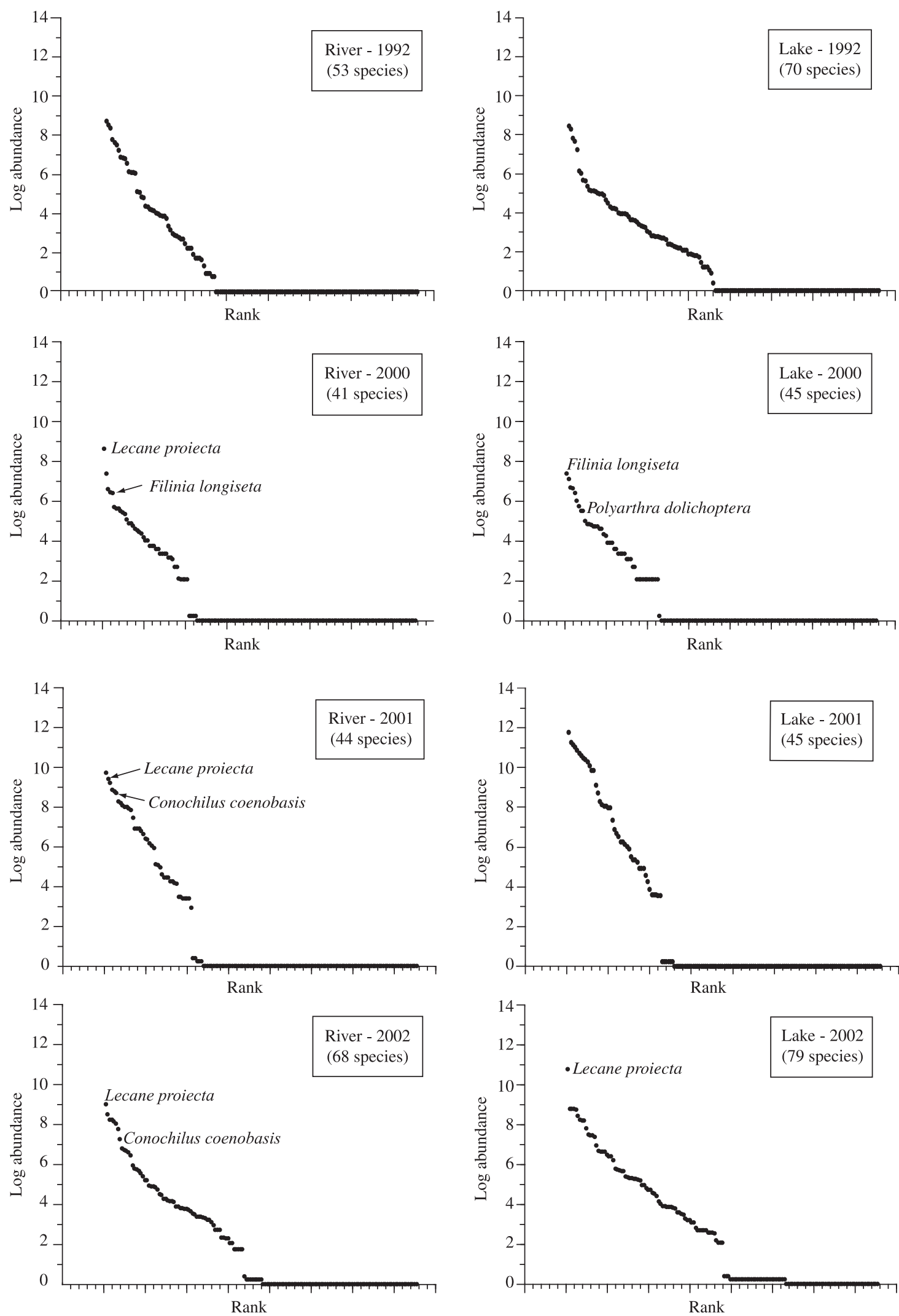

Figure 2. Curve of dominance and persistence of rotifer species registered in the two environments of the Upper Paraná River floodplain in 1992, 2000, 2001 and 2002. 

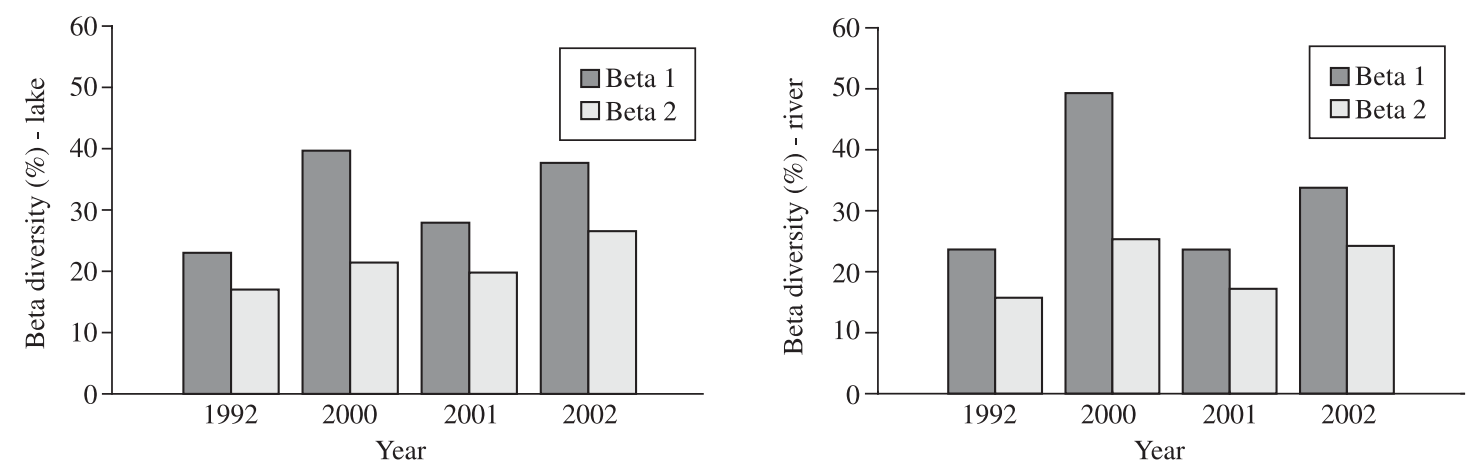

Figure 3. $\beta 1$ and $\beta 2(\%)$ diversities registered in the two environments of the Upper Paraná River floodplain in 1992, 2000, 2001 and 2002.

Table 3. Spearman correlation coefficients between the abundance of rotifer species that occurred in the river and in the floodplain lake during the four sampling years in the Upper Paraná River floodplain. Bold results show significant correlations $(\mathrm{p}<0.05)$.

\begin{tabular}{ccccccccc}
\hline & \multicolumn{9}{c}{ River } & \multicolumn{5}{c}{ Floodplain lake } \\
\cline { 2 - 10 } & $\mathbf{1 9 9 2}$ & $\mathbf{2 0 0 0}$ & $\mathbf{2 0 0 1}$ & $\mathbf{2 0 0 2}$ & $\mathbf{1 9 9 2}$ & $\mathbf{2 0 0 0}$ & $\mathbf{2 0 0 1}$ & $\mathbf{2 0 0 2}$ \\
\hline 1992 & - & 0.25 & 0.51 & 0.24 & - & 0.41 & 0.45 & 0.45 \\
2000 & - & - & 0.43 & 0.36 & - & - & 0.32 & 0.51 \\
2001 & - & - & - & 0.68 & - & - & - & 0.74 \\
\hline
\end{tabular}

such as reduced values of dissolved oxygen, $\mathrm{pH}$, turbidity and nutrients.

The increase of species richness in 2002 was related to the occurrence of the potamophase pulses and the increase of the mean intensity of these pulses, in addition to the increased connectivity between the river and its floodplain. These values were inferior to those observed before the impoundment (1992), but higher than those recorded in the 2 years following the impoundment (2000 and 2001).

In this way, it is possible to consider that the control of the regime of potamophase pulses strongly affects the biodiversity of floodplains downstream from dams (Kingsford, 2000; Bunn and Arthington, 2002; Agostinho et al., 2004), both directly, through the reduction of habitat availability as a consequence of the changes in connectivity, and indirectly, due to the alterations in limnological conditions. This influence of the hydrometrical level control on the aquatic communities is worrying when the potamophase pulses are not frequent, as observed in 2000 and 2001. A greater number of limnophase pulses were observed, mainly in 2000, and the connectivity index between the river and its floodplain was extremely low in 2001.

On the other hand, this low connectivity and the predominance of limnophase pulses, with a maximum duration of 293 days in 2001, favored the development of rotifer populations since the highest abundances were registered in this year, mainly in the floodplain lake. In this case, the absence of a dilution effect was a structur- ing factor for the community. This influence on rotifer abundance has been described in rivers and floodplain lakes by José de Paggi and Paggi (2007), Espíndola et al. (1996), Bozelli (2000), Rossa and Bonecker (2003), Bonecker et al. (2002) and Aoyagui and Bonecker (2004).

Nevertheless, in 2000 a lower abundance was verified. This year was also characterized as a dry year, although the maximum duration of limnophase pulses was lower that that observed in 2001, and the connectivity index was higher in the later year. These facts are certainly related to low values of dissolved oxygen (Rocha and Thomaz, 2004) and chlorophyll-a (Thomaz et al. 2004) in the environments. In 2000, the phytoplankton biomass, which represents food availability, was lower than in 2001, when the abundance of rotifers was high. Significant and direct relationships between chlorophyll- $a$ and rotifer abundance were found by Rossa and Bonecker (2003) in other environments on this same floodplain.

According to José de Paggi and Paggi (2007), Keppeler and Hardy (2004), Thomaz et al. (2007) and Alho (2008), the variation in the hydrometrical level in floodplain environments can be considered as a complex variable because it reflects not only the water volume in the basin, but also changes in the environmental conditions affecting the abundance of organisms directly or indirectly. These authors also considered that during the limnophase, there is a greater influence of local factors such as ecosystem productivity on the structure of 
aquatic communities, whereas regional factors such as the pulse predominate during the potamophase.

The species dominance in the floodplain lake and in the river was higher after the impoundment, probably because the low frequency of potamophase and the consequent increase in the frequency, amplitude and intensity of limnophase provide more restricted environmental conditions that favor few species. This was observed in the floodplain lake in 2000, when the lowest species richness and abundance were verified and two species dominated numerically (Polyarthra dolichoptera and Filinia longiseta). In the river, the greatest species dominance was observed in 2001, when the community was more abundant, although low species richness was registered. Lecane proiecta and Conochilus coenobasis were the dominant species.

The stability and species persistence results indicate that a greater number of species remained in the floodplain lake over the 4 study years. So, we can consider that these species were able to remain in the environment after the interannual variations of hydrometrical level of the Paraná River (characterizing their resistance to changes in their environment) and to return to the level of abundance observed before the river damming and/or after very long dry periods (characterizing their resilience), ensuring the stability of the rotifer community. According to Connell and Sousa (1983), stability analysis is a quantitative approach to changes in the relative abundance of species over time, and persistence is a qualitative perspective from which to evaluate this change; i.e., one first considers the abundance, and second, the species composition.

The river exhibited stability only between 2001 and 2002, whereas in the floodplain lake, significant stability was observed between 2002 and the other studied years. These results indicate that the community in the floodplain lake was more resistant and the community in the river was more resilient since the species rank was significantly correlated, even after 10 years of study. This suggests community recovery following the impoundment. According to Bunn and Arthington (2002), aquatic species in floodplain environments possess strategies to adjust to the natural hydrological regime or are not impacted by such changes. The persistence results also permitted description of Conochilus coenobasis, Filinia longiseta, Keratella cochlearis, Lecane proiecta and Polyarthra dolichoptera as important species in the structure of the rotifer community in the environment of the study. According to Bonecker et al. (2005), this persistence represents a typical association of dominant genera in tropical floodplains.

The lower values of $\beta$ diversity observed before the impoundment (1992) indicate that the rotifer species compositions in the two environments were more similar in this year. According to Thomaz et al. (2007), potamophase periods intensify the connectivity among floodplain environments and decrease the $\beta$ diversity of communities in these environments. On the other hand, a larger alteration in the species composition was verified soon after the impoundment (2000), mainly by the $\beta 1$ values and especially for the river, and it was related to isolation of the environments due to the high number of limnophase pulses registered throughout the study.

\section{Final Considerations}

The floodplain still present an ecosystem to be explore by rotifers since only one species persisted in the river throughout the study, and other four species persisted in the floodplain lake and in the river in some of the studied years.

The reduction in the frequency, intensity and amplitude of potamophase pulses after the impoundment was an influencing factor for the rotifers' abundance in the river and in the floodplain lake. This influence was not always direct, however, since the consequences of this hydrodynamic change also caused changes in the limnological conditions. On the other hand, the species richness remained high when maintenance of the potamophase pulses was observed, as well as before the impoundment of the Paraná River.

The community stability in the 2 environments was affected by the building of the reservoir, although the community has shown some degree of resilience and resistance to its impact. In both environments, the most effective response of the community to the impoundment was recorded in the last two years.

Acknowledgements - We thank M.Sc. Nadson R Simões, M.Sc. Erica M Takahashi, and M.Sc. Juliana Déo Dias for suggestions and help with the analysis. The research was supported by PELD (site 6)/CNPq and NupéliaUEM. Scholarships to CCB and RMS were provided by CNPq and to ASA by CAPES.

\section{References}

AGOSTINHO, AA., THOMAZ, SM. and GOMES, LC., 2004. Threats for biodiversity in the floodplain of the Upper Paraná River: effects of hydrological regulation by dams. Ecohydrology \& Hydrobiology, vol. 4, no. 3, p. 267-289.

ALHO, CJR., 2008. Biodiversity of the Pantanal: response to seasonal floodplain regime and to environmental degradation. Revista Brasileira de Biologia = Brazilian Journal of Biology, vol. 68 , no. 4, p. $957-966$

ALLAN, JD., 1976. Life history patterns in zooplankton. The American Naturalist, vol. 110, no. 971, p. 165-180.

AOYAGUI, ASM. and BONECKER, CC., 2004. The art status of rotifer studies in natural environments of South America: floodplains. Acta Scientiarum, vol. 26, no. 4, p. 385-406.

BONECKER, CC., COSTA, CL., VELHO, LFM. and LANSACTÔHA, FA., 2005. Diversity and abundance of the planktonic rotifers in different environments of the Upper Paraná River floodplain (Paraná State - Mato Grosso do Sul State, Brazil). Hydrobiologia, vol. 546, no. 1, p. 405-414.

BONECKER, CC., LANSAC-TÔHA, FA., BINI, LM. and VELHO, LFM., 2002. Daily fluctuation in rotifer population abundance in two environments of the Upper Paraná river floodplain, Brazil. Amazoniana, vol. XVII, no. 1-2, p. 139-151.

BOTTRELL, HH., DUNCAN, A., GLIWICZ,Z., GRYGIEREK, E., HERZIG, A., HILLBRICHT-ILLKOWSKA, A., 
KURASAWA, H., LARSSON, P. and WEGLENSKA, T., 1976. A review of some problems in zooplankton production studies. Norwegian Journal of Zoology, vol. 24, no. 4, p. 419-456.

BOZELLI, RL., 2000. Zooplâncton. In BOZELLI, RL., ESTEVES, FA. and ROLAND, F. (Eds.). Lago Batata: impacto e recuperação de um ecossistema amazônico. Rio de Janeiro: IB-UFRJ; SBL. p. 119-138.

BUNN, SE. and ARTHINGTON, AH., 2002. Basic principles and ecological consequences of altered flow regimes for aquatic biodiversity. Environmental Management, vol. 30, no. 4, p. $492-507$.

CONNELL, JH. and SOUSA, WP., 1983. On the evidence needed to judge ecological stability or persistence. The American Naturalist, vol. 121, no. 6, p. 789-824.

ESPÍNDOLA, EG., MATSUMURA-TUNDISI, T. and MORENO, IH., 1996. Efeitos da dinâmica hidrobiológica do sistema Pantanal matogrossense sobre a estrutura da comunidade de zooplâncton da lagoa Albuquerque. Acta Limnologica Brasiliensia, vol. 8, p. 37-57.

JOSÉ De PAGGI, S. and PAGGI, JC., 2007. Zooplankton. In IRIONDO, MH., PAGGI, JC. and PARMA, MJ. (Eds.). The Middle Paraná River: limnology of a subtropical wetland. New York: Springer. p. 229-250.

JUNK, WJ., BAYLEY, PB. and SPARKS, RE., 1989. The flood pulse concept in river-floodplain systems. Canadian Special Publication of Fisheries and Aquatic Sciences, vol. 106, p. $110-127$.

KEPPELER, EC. and HARDY, ER., 2004. Abundance and composition of Rotifera in an abandoned meander lake (Lago Amapá) in Rio Branco, Acre, Brazil. Revista Brasileira de Zoologia, vol. 21, no. 2, p. 233-241.

KINGSFORD, RT., 2000. Ecological impacts of dams, water diversions and river management on floodplain wetlands in Australia. Austral Ecology, vol. 25, no. 2, p. 109-127.

LANSAC-TÔHA, FA., BONECKER, CC. and VELHO, LFM., 2004. Composition, species richness and abundance of the zooplankton community. In THOMAZ, SM., AGOSTINHO, AA. and HAHN, NS. (Eds.). The Upper Paraná River and its floodplain: physical aspects, ecology and conservation. Leiden: Backhuys Publishers. p. 145-190.

LANSAC-TÔHA, FA., BONECKER, CC., VELHO, LFM., SIMÕES, NR., DIAS, JD., ALVES, GM. and TAKAHASHI, EM., 2009. Biodiversity of zooplankton communities in the Upper Paraná River floodplain: interannual variation from longterm studies. Revista Brasileira de Biologia = Brazilian Journal of Biology, vol. 69, no. (2 suppl), p. 539-549.

McCANN, KS., 2000. The diversity-stability debate. Nature, vol. 405 , no. 11 , p. 228-233.

NEIFF, JJ., 1990. Ideas para la interpretación ecologica del Paraná. Interciencia, vol. 15, no. 6, p. 424-441.

2001. Diversity in some tropical wetland systems of South America. In GOPAL, B., JUNK, WJ. and DAVIS, JA. (Eds.). Biodiversity in wetland: assessment function and conservation. Leinden; The Netherlands: Backhuys Publishers. p. 157-186.
NEIFF, JJ. and NEIFF, M., 2003. PULSO: software para análisis de fenómenos recurrentes. Buenos Aires. Dirección Nacional de Derecho de Autor $n^{\circ}$. 236164. (Argentina). Available from: $<$ http://www.neiff.com.ar>.

NEVES, IF., ROCHA, O., ROCHE, KF. and PINTO, AA., 2003. Zooplankton community structure of two marginal lakes of the River Cuiabá (Mato Grosso, Brazil) with analysis of Rotifera and Cladocera diversity. Revista Brasileira de Biologia = Brazilian Journal of Biology, vol. 63, no. 2, p. 329-343

PIMM, SL., 1984. The complexity and stability of ecosystems. Nature, vol. 307, no. 5949, p. 321-326.

ROCHA, RRA. and THOMAZ, SM., 2004. Variação temporal de fatores limnológicos em ambientes da planície de inundação do alto rio Paraná (PR/MS-Brasil). Acta Scientiarum Biological Science, vol. 26, no. 3, p. 261-271.

ROSSA, DC. and BONECKER, CC., 2003. Abundance of planktonic and non-planktonic rotifers in floodplain lakes of the Upper Paraná River floodplain. Amazoniana, vol. XVII, no. 3-4, p. $567-581$

SCARSBROOK, MR., 2002. Persistence and stability of lotic invertebrate communities in New Zealand. Freshwater Biology, vol. 47 , no. 3, p. 417-431

SOKAL, RR. and ROHLF, RJ., 1981. Biometry. 2 ed. New York: W.H. Freeman and Company. 859pp.

STATSOFT INCORPORATION, 2005. Statistica for Windows. Tulsa: STATSOFT Inc. Available from: <http://www.statsoft. com>.

THOMAZ, SM., BINI, LM. and BOZELLI, RL., 2007. Floods increase similarity among aquatic habitats in river-floodplain systems. Hydrobiologia, vol. 579, no. 1, p. 1- 13.

THOMAZ, SM., PAGIORO, TA., BINI, LM., ROBERTO, MC. and ROCHA, RRA., 2004. Limnological characterization of the aquatic environments and the influence of hydrometric levels. In THOMAZ, SM., AGOSTINHO, AA. and HAHN, NS. (Eds.). The Upper Paraná River and its floodplain. Leiden: Backhuys Publishers. p. 75-102.

VELHO, LFM., BINI, LM. and LANSAC-TÔHA, FA., 2004. Testate amoeba (Rhizopoda) diversity in plankton of the Upper Paraná River floodplain, Brazil. Hydrobiologia, vol. 523, no. 1-3, p. 103-111.

WARD, JV. and STANFORD, JA, 1995a. The serial discontinuity concept: extending the model to floodplain rivers. Regulated Rivers: Research and Management, vol. 10, no. 2-4, p. $159-168$.

WARD, JV. and TOCKNER, K., 2001. Biodiversity: towards a unifying theme for river ecology. Freshwater Biology, vol. 46, no. 6 , p. 807-819.

WARD, JV., TOCKNER, K. and SCHIEMER, F., 1999. Biodiversity of floodplain river ecosystems: ecotones and connectivity. Regulated Rivers: Research and Management, vol. 15 , no. $1-3$, p. 125-139.

WHITTAKER, RH., 1960. Vegetation of the Siskiyou Mountains. Oregon and California. Ecological Monographs, vol. 30, no. 3, p. 279-338.

ZAR, JH., 1999. Biostatistical analysis. New Jersey: Prentice Hall. 663pp. 